\title{
Non-African representatives of the plesiomorphion Protopatellata (Ephemeroptera: Baetidae)
}

\author{
Внеафриканские представители плезиоморфона Protopatellata \\ (Ephemeroptera: Baetidae)
}

\author{
Nikita J. Kluge \\ Н.Ю. КАюге
}

Department of Entomology, St. Petersburg State University, Universitetskaya nab., 7/9, St. Petersburg 199034, Russia. E-mail: kluge@FK13889.spb.edu. Website: http://www.insecta.bio.pu.ru

Кафедра энтомологии, биолого-почвенный факультет, С.-Петербургский государственный университет, Университетская наб., 7/8, С.-Петербург 199034, Россия.

KEY WORDS: systematics, Ephemeroptera, Baetidae, Protopatellata, Indocloeon, Anafroptilum, new species.

КЛЮЧЕВЫЕ СЛОВА: систематика, Ephemeroptera, Baetidae, Protopatellata, Indocloeon, Anafroptilum, новый вид.

ABSTRACT. Indocloeon, described as larvae of a single species from Sri Lanka, appears to belong to the plesiomorphon Protopatellata, which formerly was known from Africa only. Indocloeon primum is redescribed as larvae and male and female imagoes reared from larvae. A new species Indocloeon indonesiae sp.n. is described as male and female imagoes reared from larvae from Lombok Island in Indonesia. A new genus Anafroptilum gen.n. is establishes for the East-Palaearctoc species originally described as Centroptilum kazlauskasi Kluge, 1983 and some Nearctic species formerly attributed to the genus Centroptilum; their patella-tibial suture is developed on middle and hind legs only, that is characteristic for Protopatellata.

РЕЗЮМЕ. Установлено, что Indocloeon, описанный по личинкам одного вида из Шри Ланки, относится к плезиоморфону Protopatellata, ранее известному только из Африки. Indocloeon primum переописывается по личинкам и выведенным из личинок самцам и самкам имаго. По самцам и самкам имаго, выведенным из личинок с острова Ломбок в Индонезии, описывается новый вид Indocloeon indonesiae sp.n. Установлен новый род Anafroptilum gen.n., включающий восточно-палеарктический вид, исходно описанный как Centroptilum kazlauskasi Kluge, 1983, и некоторые неарктические виды, ранее помещавшиеся в род Centroptilum; у них пателло-тибиальный шов развит только на средних и задних ногах, что свойственно Protopatellata.

\section{Introduction}

All Baetidae s.str., or Turbanoculata Kluge, 1997, are divided into a plesiomorphon Protopatellata Kluge \& Novikova, 2011 and a holophyletic taxon Anteropatellata Kluge, 1997. The taxon Protopatellata is charac-

Printed in 2012 terized by retaining the same primitive position of patella-tibial suture, which occurs in most Ephemeroptera: in all stages of both sexes this suture is developed on middle and hind legs, but absent on fore legs; in selected taxa patella-tibial suture is reduced on all legs, but it never appears on fore legs. The taxon Anteropatellata is characterized by an autapomorphy: patella-tibial suture is restored on fore legs, which become similar to middle and hind legs; only in male subimago and imago fore legs lack patella-tibial suture (see Table).

Table. Presence of patella-tibial suture in Protopatellata and Anteropatellata. Таблица. Наличие пателло-тибиального шва y Protopatellata и Anteropatellata

\begin{tabular}{|c|l|c|c|c|c|c|c|}
\hline \multicolumn{2}{|c|}{} & \multicolumn{3}{c|}{ male } & \multicolumn{3}{c}{ female } \\
\cline { 3 - 9 } \multicolumn{2}{c|}{} & $\begin{array}{c}\text { fore } \\
\text { leg }\end{array}$ & $\begin{array}{c}\text { middle } \\
\text { leg }\end{array}$ & $\begin{array}{c}\text { hind } \\
\text { leg }\end{array}$ & $\begin{array}{c}\text { fore } \\
\text { leg }\end{array}$ & $\begin{array}{c}\text { middle } \\
\text { leg }\end{array}$ & $\begin{array}{c}\text { hind } \\
\text { leg }\end{array}$ \\
\hline \hline \multirow{2}{*}{$\begin{array}{l}\text { plesiomorphon } \\
\text { Protopatellata }\end{array}$} & larva & - & + & + & - & + & + \\
\cline { 2 - 9 } & subimago & - & + & + & - & + & + \\
\cline { 2 - 9 } & imago & - & + & + & - & + & + \\
\hline \hline \multirow{3}{*}{\begin{tabular}{l} 
Anteropatellata \\
\cline { 2 - 9 }
\end{tabular}} & larva & + & + & + & + & + & + \\
\cline { 2 - 9 } & Subimago & - & + & + & + & + & + \\
\cline { 2 - 9 } & imago & - & + & + & + & + & + \\
\hline
\end{tabular}

The taxon Protopatellata is abundant in Afrotropical region (including South Africa and Madagascar), where it is represented by more than 60 species forming a wide range of morphological forms. Non-African representatives of Protopatellata had been unknown yet. Three Asian baetid species with the primitive position of patella-tibial suture are described below.

Morphological terms used here, are explained in the previous paper [Kluge \& Novikova, 2011].

All material, including holotypes and paratypes of the new species, is permanently deposited in the Zoological Institute of Russian Academy of Sciences (Saint 
Petersburg, Russia); temporarily locates in the Department of Entomology of Saint Petersburg State University. In the lists of material examined, the following arbitrary signs are used: L-S-I $\sigma^{7}$ — male imago reared from larva, with larval and subimaginal exuviae; L-S-I 9 - female imago reared from larva, with larval and subimaginal exuviae.

\section{General classification of Baetidae}

Here phylogenetic classification of Baetidae is accepted as the following (some poorly known taxa are not included):

1. Turbanoculata Kluge, 1997, or Baetis/fg4 [f: Baetida Leach, 1815; g: Baetis Leach, 1815], or family Baetidae s.str. Characterized by a number of unique apomorphies [Kluge, 2004]. Distributed World-Wide, except New Zealand.

1.1. Plesiomorphion Protopatellata Kluge \& Novikova, 2011, or Afroptilum/f1=Centroptiloides/g1 [f: Afroptilinae Kluge, 1997; g: Centroptiloides Lestage, 1918], or subfamily Afroptilinae sensu Kluge 1997. Characterized by plesiomorphic absence of patella-tibial suture on fore legs. Distributed mainly in Ethiopian Region; a few species in Asia and North America (see below).

2.2. Anteropatellata Kluge, 1997, or Baetis/fg5. Characterized by restoring patella-tibial suture on fore legs of larva and female adults. Distributed World-Wide, except New Zealand.

2.2.1. Cloeon/fg1 [f: Cloeonidae Newman, 1853; g: Cloeon Leach, 1815]. Characterized by presence of spines on lateral margins of last abdominal segments in larva and other characters. Distributed in Holarctic, Ethiopian, Oriental Regions and Australia.

2.2.1.1. Plesiomorphon Similicloeon/g1 [g: Similicloeon Kluge \& Novikova, 1992] (including Intercloeon Kluge \& Novikova, 1992).

2.2.1.2. Cloeon/fg2. Characterized by strongly widened, double tergalii of peculiar shape in larva, triangular median projection of penial bridge of male imago, colored fore wing margin in female imago and viviparity. Distributed in Holarctic, Ethiopian, Oriental Regions and Australia.

2.2.1.3. Procloeon/g1 [g: Procloeon Bengtsson, 1915]. Characterized by presence of one large spine on lateral side of each segment in distal part of larval cercus [Kluge \& Novikova, 1992: Fig. 9:19]. Distributed in Holarctic, Ethiopian and Oriental Regions.

2.2.1.3.1. Plesiomorphon Procloeon/g2. Distributed in Holarctic, Ethiopian and Oriental Regions.

2.2.1.3.2. Austrocloeon/g(1) [g: Austrocloeon Barnard, 1940]. Characterized by a single vein in pterostigma and viviparity. Distributed in Ethiopian Region.

2.2.1.3.3. Pseudocentroptiloides/g1 [g: Pseudocentroptiloides Jacob, 1987]. Characterized by peculiar modification of labium. Distributed in Holarctic, Ethiopian and Oriental Regions.

2.2.1.3.3.1. Plesiomorphon Securiops/g(1) [g: Securiops Jacobus et al., 2006]. Distributed in Ethiopian Region.

2.2.1.3.3.2. Pseudocentroptiloides/g2. Characterized by peculiar shape of labrum. Distributed in Holarctic and Oriental Regions.

2.2.2. Centroptilum/g1 [g: Centroptilum Eaton, 1869] (see below).

2.2.3. Baetopus/g1 [g: Baetopus Keffermuller, 1960]. Characterized by 2 -segmented labial palp. Distributed in Holarctic and Oriental Regions.
2.2.3.1. Plesiomorphon Baetopus/g2 . Distributed in Holarctic.

2.2.3.2. Raptobaetopus/g(1) [g: Raptobaetopus MüllerLiebenau, 1978]. Characterized by peculiar modification of mouth apparatus. Distributed in Palaearctic and Oriental Regions.

2.2.4. Cheleocloeon/g(1) [g: Cheleocloeon Wuillot \& Gillies, 1993]. Characterized by paddle-shaped enlarged tergalius I and inner-apical projection on $2^{\text {nd }}$ segment of labial palp. Distributed in Africa and Arabia.

2.2.5. Afrobaetodes/g(1) [g: Afrobaetodes Demoulin, 1970]. Characterized by ventral shifting of tergalii and adaptation for rheophilous inhabitance. Distributed in Ethiopian Region.

2.2.6. Baetovectata Kluge \& Novikova, 2011, or Baetis/fg6. Characterized by peculiar structure of penial gonovectes, double intercalaries in each space of fore wing and non-lateral direction of $2^{\text {nd }}$ segment subimaginal gonostylus when it develops under larval cuticle [Kluge \& Novikova, 2011]. Includes most Baetidae; distributed World-Wide, except New Zealand.

\section{Non-African taxa of Protopatellata}

Out of Ethiopian Region, the plesiomorphon Protopatellata is represented by Oriental genus Indocloeon Müller-Liebenau, 1982 with two species - I. primum Müller-Liebenau, 1982 and I. indonesiae sp.n. and Amphipacific genus Anafroptilum gen.n. with a single East-Palaearctic species A. kazlauskasi (Kluge, 1983) comb.n. and several Nearctic species.

\section{Indocloeon Müller-Liebenau, 1982 Figs 1-37.}

TYPE SPECIES: Indocloeon primum Müller-Liebenau, 1982.

LARVA. Cuticle of abdominal terga nearly unicolor, without contrasting markings or blanks; cuticle of abdominal sterna nearly colorless. Cuticular pigmentation of other body parts species-specific.

Head rather narrow; frons between antennae forms elevation more or less narrowing anteriorly; margins of this elevation can somewhat overlap antennal bases (Fig. 1). Mandibles (Figs 16-17) [Müller-Liebenau, 1982: Fig. 1h]: Left mandible has incisor and kinetodontium fused up to apex; distalmost denticle of incisor turned ventrally and terminates far from apex; prostheca very massive; setae proximad of prostheca either present (in I. indonesiae) or absent (in $I$. primum). Right mandible has incisor and kinetodontium fused at most length; distalmost denticle of incisor turned ventrally and terminates far from apex; prostheca stick-like, pressed to kinetodontium; proximad of prostheca a row of setae. Hypopharynx with median tuft of stout setae-like spines, which are brought together, but not coalescent. Maxilla (Fig. 5) [Müller-Liebenau, 1982: Fig. 1e]: biting edge narrow; 3 canines and distal dentiseta teeth-like, curved at the same direction; middle and proximal dentisetae more slender; maxillary palp long and slender, differs in two species. Labium (Fig. 3) [Müller-Liebenau, 1982: Fig. 1b-d]: glossal and paraglossal muscles attached at one point near base of mentum; $2^{\text {nd }}$ segment of labial palp has projected medio-apical angle and contains muscle moving $3^{\text {rd }}$ segment.

Pronotum short, without projected antero-lateral angles, with straight transverse ridge near anterior margin; mesonotum with hind margin projected between protoptera (Fig. 4). Metanotum without vestiges of hind protoptera [Müller-Liebenau, 1982: Fig. 1f]. Meso- and metathoracic pleura and legs bear 
scales in angulate bases with opercula at angles (Fig. 15), similar to that on abdominal terga and sterna (Fig. 6). Legs slender; femora of all legs slender and parallel-sided, fore femur somewhat thicker and shorter than middle and hind femora; fore tibia somewhat shorter than middle and hind tibiae; fore tarsus somewhat longer than middle and hind tarsi (Figs 13-14). Patella-tibial suture present on middle and hind legs (Fig. 15), absent on fore legs. Femora, tibiae and tarsi have stout pointed bipectinate setae, which do not form regular rows; these bipectinate setae are most numerous on inner side of fore femur (Fig. 13), less numerous on inner side of middle and hind femora (not shown in Fig. 14). Outer margin of femur lacks longitudinal row of stout setae (in profile view irregular pectinate setae can be confused with such row - Fig. 14); apex of each femur with two stout blunt non-pectinate dark brown setae (Fig. 15). Claw slender, slightly bent, with 2 rows of denticles, among which 3-4 distalmost denticles larger and directed distally, and other denticles very small (Fig. 12) [Müller-Liebenau, 1982: Fig. 1j].

Abdomen narrow, equally convex dorsally and ventrally: being spread on slide, terga and sterna have equal width; tergum width between tergalii bases $2 \frac{1}{4}-2 \frac{1}{2}$ of tergim length; fore margins of terga and sterna strongly convex in middle part [Müller-Liebenau, 1982: Fig. 2]. Lateral margins of all abdominal segments lack spines or denticles (unlike Cloeon/fg1 and Anafroptilum). Terga and sterna covered by fine, longitudinally striated scales, situated in angulate nests, whose angles bear operculae (Fig. 6); in Indocloeon primum these scales can be arranged in irregular transverse rows [Müller-Liebenau, 1982: Fig. 3]. Denticles on hind margins of abdominal terga and sterna differ in I. indonesiae and I. primum. Paraprocts bear scales in angulate nests and regular denticles on medioposterior margin (Fig. 8). Tergalii able for rhythmical respiratory vibration. Tergalii I-VI with anal margin more convex than costal margin; tergalius VII with anal margin less convex than costal margin (Figs 9-11). Costal rib on tergalius I short, on tergalii II-VII long, terminate near tergalius apex and bear denticles in apical part. Anal rib on tergalius I absent, on tergalius II short, on next tergalii longer, on tergalius VII terminates near tergalius apex. All tergalii with tracheae dense and blackish. Cerci long, paracercus twice shorter than cerci. At proximal half of cercus (equal to paracercus length) swimming setae well developed; at distal half of cercus swimming setae absent. Paracercus has swimming setae nearly up to its tip, only several very thin apical segments lack setation. Each swimming seta is thick and pigmented in proximal half and thin and colorless in distal half (Fig. 7).

In mature male larva subimaginal gonostyli developing under larval cuticle are folded as following: $2^{\text {nd }}$ segment bent laterally; $3^{\text {rd }}$ segment bent medially and curved anteriorly (Fig. 35). This mode of folding corresponds to the «Cloeontype» which is usual for Protopatellata, but it looks unusual due to the fact that $2^{\text {nd }}$ segment is very short and $3^{\text {rd }}$ segment is very long, as in imago.

SUBIMAGO AND IMAGO. Fore wings with no more than one marginal intercalary in each space. Hind wings absent. On middle and hind legs tibia slightly longer than femur; tarsus $1 / 2$ of tibia length; proximal $\left(1^{\text {st }}+2^{\text {nd }}\right)$ tarsal segment long; tarsus has one apical thorn on $3^{\text {rd }}$ tarsomere only, while $1^{\text {st }}+2^{\text {nd }}$ and $4^{\text {th }}$ tarsomeres lack apical-ventral thorns (Fig. 19). On fore leg of female tarsus also has one apical thorn on $3^{\text {rd }}$ tarsomere only (Fig. 20). In subimago of both sexes all segments of all tarsi covered with pointed microlepides.

Male genitals have peculiar structure (Figs 23-25, 2729, 32-33): Styligeral muscle wide, paired, its left and right halves convergent toward styliger (Figs 24, 32). Unistyligers (i.e., gonostyli pedestals, or lateral parts of styliger containing styligeral muscles) widely separated and poorly expressed. Proximal $\left(1^{\mathrm{st}}+2^{\text {nd }}\right)$ segment of gonostylus unusually short. Distal $\left(3^{\text {rd }}\right)$ segment of gonostylus unusually long; in subimago nearly as long as in imago (compare Figs 23 and 24, 27 and 28, 32 and 33), develops under larval cuticle without crumpling (Fig. 35). Penial bridge with wide rectangular median projection; gonovectes of penis short, at most membranous.

COMPARISON. As in most Protopatellata, all stages (larva, subimago and imago) of both sexes of Indocloeon have patella-tibial suture developed only on middle and hind legs and absent on fore legs (Figs 13-14) . Probably, MüllerLiebenau [1982: Fig.1i] wrongly indicated a larval leg with developed patella-tibial suture as "1st leg".

Indocloeon differs from all known baetids by genital structure with wide styliger, short $1^{\text {st }}+2^{\text {nd }}$ segments of gonostyli and long $3^{\text {rd }}$ segments of gonostyli (Figs 24, 28, 32). Unlike most Protopatellata, gonovectes are vestigial and membranous (Figs 24, 29, 32).

Larva of Indocloeon resembles Cheleocloeon in having slender legs (Figs 13-14) combined with chelate labial palp (Fig. 3); it differs from Cheleocloeon by absence of patellatibial suture on fore legs (Fig. 13), elevated frons (Fig. 1), and non-enlarged first tergalii (Fig. 9).

DISTRIBUTION. Oriental Region: known from Sri Lanka and Lombok.

SPECIES COMPOSITION. Indocloeon primum MüllerLiebenau, 1982 (Sri Lanka) and I. indonesiae sp.n. (Lombok).

SYSTEMATIC POSITION. Indocloeon undoubtedly belongs to Turbanoculata, or Baetidae s.str., but has no synapomorphies with any other group within Turbanoculata. Symplesiomorphy with Protopatellata (presence of patella-tibial suture only on middle and hind legs of all stages of both sexes) allows to attribute it to the plesiomorphon Protopatellata.

\section{Indocloeon indonesiae Kluge, sp.n.} Figs 1-30.

MATERIAL. Holotype: L-S-I $0^{7}\{$ specimen $[\mathrm{XL}](7)\}$ : Indonesia, Island Lombok, Senaru, 25.IX.2009, coll. N. Kluge and L. Sheyko. Paratypes: the same locality, 19-26.IX.2009: 1 L-S-IO', 1 L-S-I 9 , 2 larvae.

LARVA. Cuticular COLORATION: Cuticle of head brown, with blanks in front of median ocellus and between eyes and lateral ocelli. Pronotum and mesonotum brown, sometimes with diffusive lighter and darker markings; median longitudinal molting suture light; protoptera with darker and lighter stripes along some longitudinal veins. Thoracic sclerites brown, sterna lighter. Legs have diffusive lighter and darker areas: femur in proximal half light, distally with dark band, apex light, apical flaps dark; tibia in proximal half dark (on middle and hind legs with contrasting light patella-tibial suture), in distal part light; tarsus at most part dark, apex and claw light. All abdominal terga I-IX nearly uniformly brown, sometimes with small diffusive light blanks near anterior margin; tergum X lighter, with hind margin dark. Abdominal sterna lighter than terga. Caudalii nearly uniformly brown.

Hypodermal Coloration: Not expressed.

SHAPE AND SETATION: Labrum with paired anterior-lateral row of setae located close to anterior margin, one seta locates between this row and submedian seta (Fig. 2). Left mandible proximad of prostheca has a small bunch of setae directed proximally (Fig. 16). Maxillary palp indistinctly 3 -segmented, with $3^{\text {rd }}$ segment long (Fig. 5). Glossa apically somewhat 
wider than in I. primum, with three rows of apical setae, ventrally with oblique row of 4 setae; projected medio-apical angle of $2^{\text {nd }}$ segment of labial palp not pointed (Fig. 3). Hind margin of each tergum bears regular row of sclerotized triangular denticles, which are long on posterior terga (Fig. 6) and shorter on anterior terga, so that on tergum I they are equilateral. Hind margins of sterna I-III lack denticles; sternum IV with small denticles; each sternum V-VIII of male and each sternum V-IX of female with regular long triangular sclerotized denticles similar to denticles on terga. Sternum IX of male bears long triangular denticles by sides of protogonostyli and very thin and dense denticles between protogonostyli. At proximal half of cercus (which bears swimming setae see characteristics of Indocloeon) each $4^{\text {th }}$ segment bears several stout spines on lateral side, other segments have smaller spines (Fig. 7); at distal half of cercus (which lacks swimming setae) all segments have no lateral spines.

SUBimago. Cuticular coloration: Cuticle of head and prothorax colorless. Cuticle of mesonotum nearly colorless, only lateral sclerite of parascutellum brown. Cuticle of

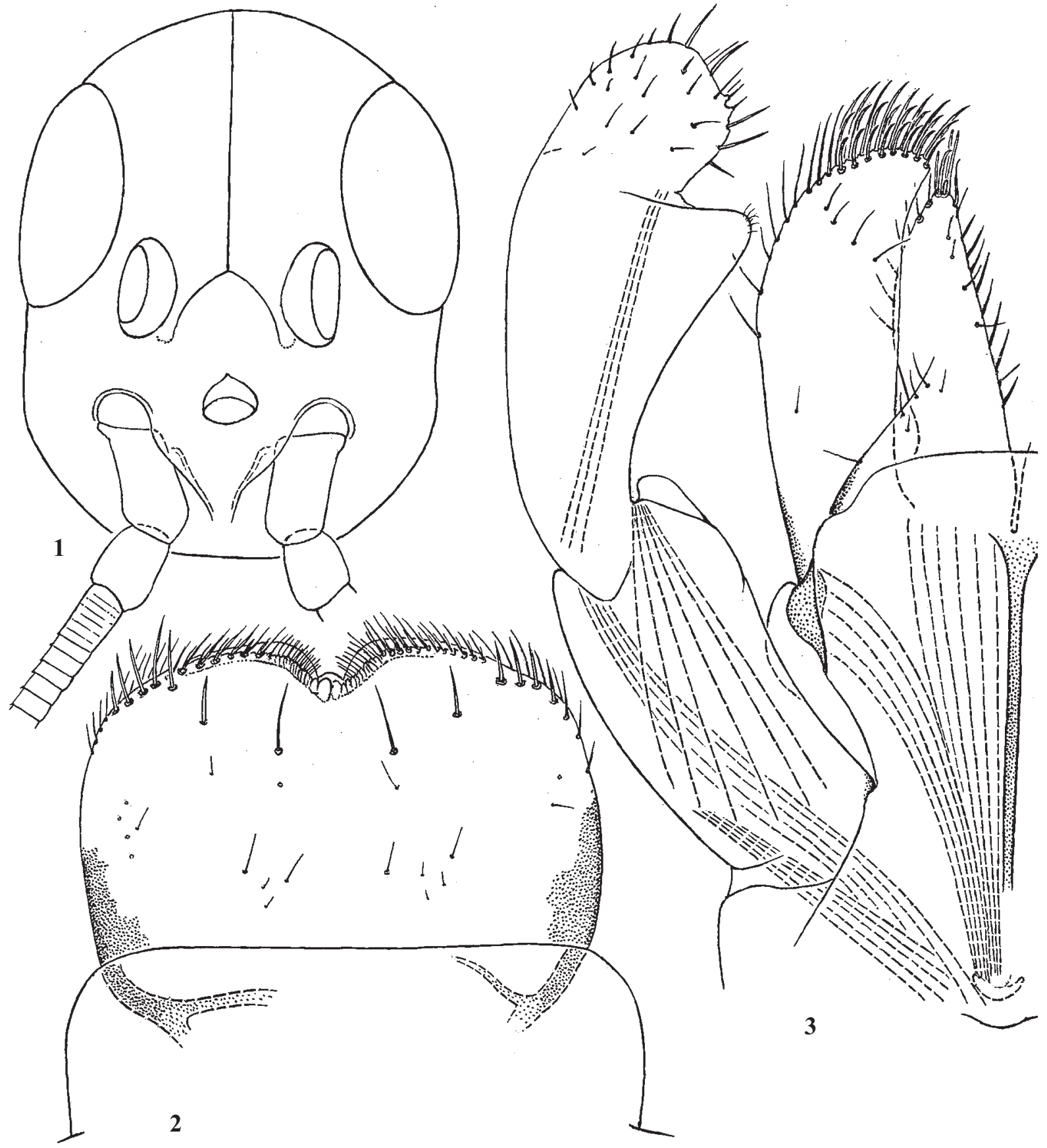

Figs 1-3. Indocloeon indonesiae sp.n., last instar larva: 1 - head of female larva, front view; 2 - labrum; 3 - half of labium, ventral view (muscles and setae on dorsal side of $2^{\text {nd }}$ palpomere shown by interrupted lines).

Рис. 1-3. Indocloeon indonesiae sp.n., личинка последнего возраста: 1 - голова личинки самки, вид спереди; 2 - верхняя губа; 3 половина нижней губы, вентрально (мышцы и щетинки на дорсальной стороне второго членика щупика показаны прерывистыми линиями). 
pleura at most colorless, with a few brownish stripes; postsubalar sclerite brown, high and short, with antero-dorsal angle stretched and curved, postero-dorsal angle shortly stretched (Fig. 26). Legs colorless. Wings light. Cuticle of abdomen colorless or tinged with pale brownish. Cerci colorless.

Hypodermal COLORATION: As in imago.
IMAGO, MALE. Head pale ocher. Antennae pale; scapus with dark brown spot near apex, pedicellus with distal half brown (Fig. 30). Turban eyes large (Fig. 30); facetted surface yellow; stem in proximal part light red, in distal part lighter. Medionotum of mesothorax light brown; other parts of thorax at most pale ocher, with a few small brown markings;

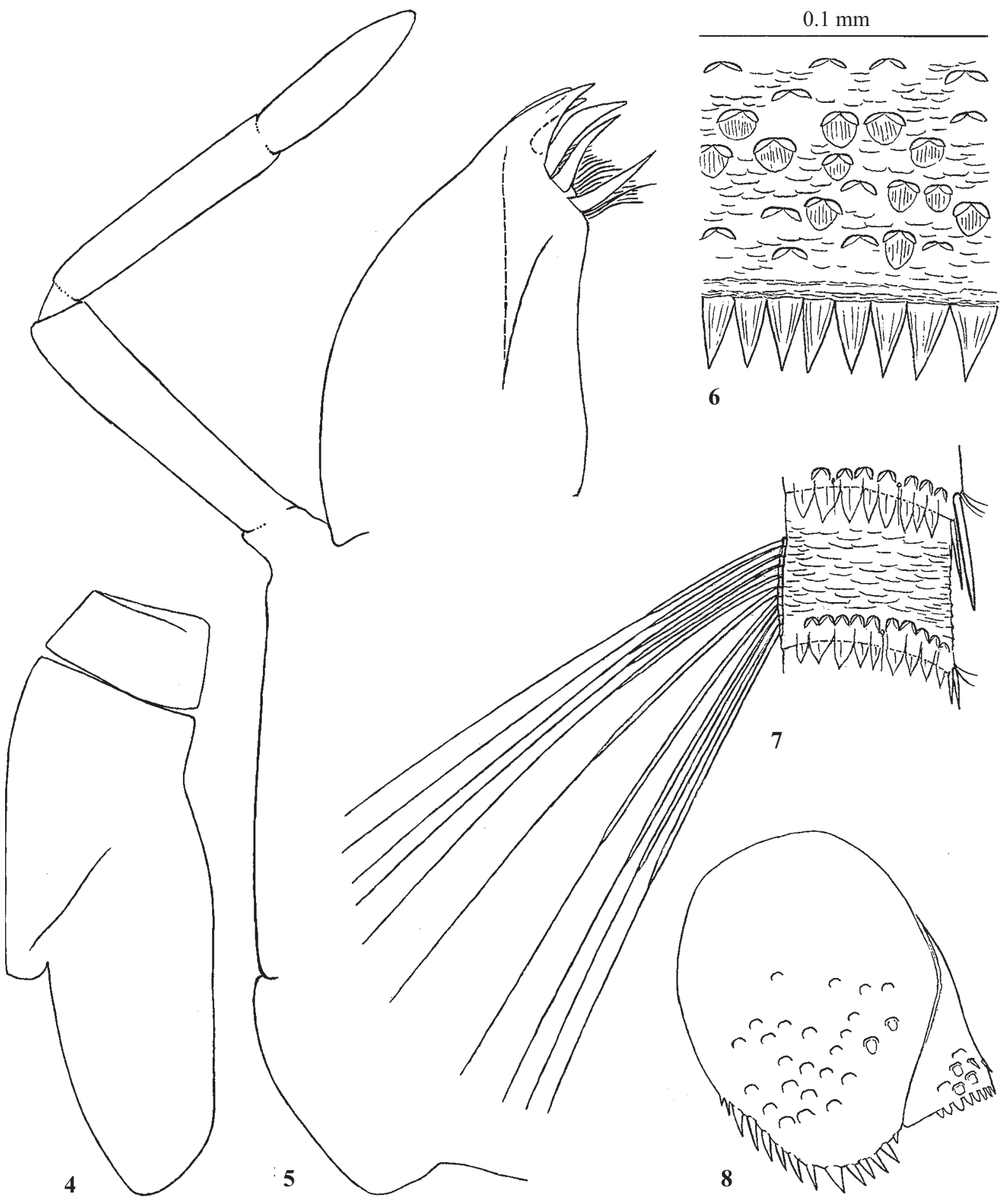

Figs 4-8. Indocloeon indonesiae sp.n., last instar larva: 4 - exuviae of right half of pronotum and mesonotum (holotype); 5 - maxilla; 6 - hind margin of abdominal tergum VII; 7 - segment of cercus about 1/3 from cercus base, the same scale; 8 - paraproct.

Рис. 4-8. Indocloeon indonesiae sp.n., личинка последнего возраста: 4- экзувий правой половины пронотума и мезонотума (голотип); 5 - максилла; 6 - задний край VII тергита брюшка; 7 - членик церка около 1/3 от основания церка, в том же масштабе; 8 - парапокт. 
ventral part lighter (Fig. 30). Legs colorless. Wings colorless, all veins pale; pterostigma with 3 crossveins; short single marginal intercalary in some spaces (Fig. 18). Abdominal segments I-VII translucent and colorless, with dark lateral tracheal trunks; terga VIII and IX reddish medially, with white lateral parts; segment X light. Cerci colorless.

Genitals as characterized for Indocloeon (Figs 23-25, 27-29). Styliger colorless. $1^{\text {st }}+2^{\text {nd }}$ segment of gonostylus has proximal swollen part colorless and covered by small spinelike microtrichiae; distal narrow part brown, covered with brown blunt microlepides, which are longer on inner side. Shape of this segment is quite variable, being different in two specimens examined (Figs 24 and 28). Distal $\left(3^{\text {rd }}\right)$ segment of gonostylus straight, brown, covered with brown blunt microlepides, which are longer on inner side. Penis brown.
IMAGO, FEMALE. Head pale ocher with brown markings between eyes; antennae as in male (Fig. 22). Pronotum with ornament of contrasting ocher and brown areas. Mesonotum pale ocher, with medionotum slightly darker. Thoracic pleura with ocher and brownish maculation. Ventral part of thorax pale. Legs colorless. Wings as in male. Abdomen with intensive pigmentation: terga I-IX brown, with median part darker, lateral parts pale ocher and contrastingly outlined; tergum X light with posterior margin brown; pleura II-VIII pale ocher, each with a pair of contrasting brown wedge-formed stripes by sides; sternum IX at most brownish; tracheal trunks bordered by blackish (Fig. 21).

EGG. Oval, about $0.15 \mathrm{~mm}$ length; surface without regular relief.

DIMENSION. Fore wing length 4-5 mm.

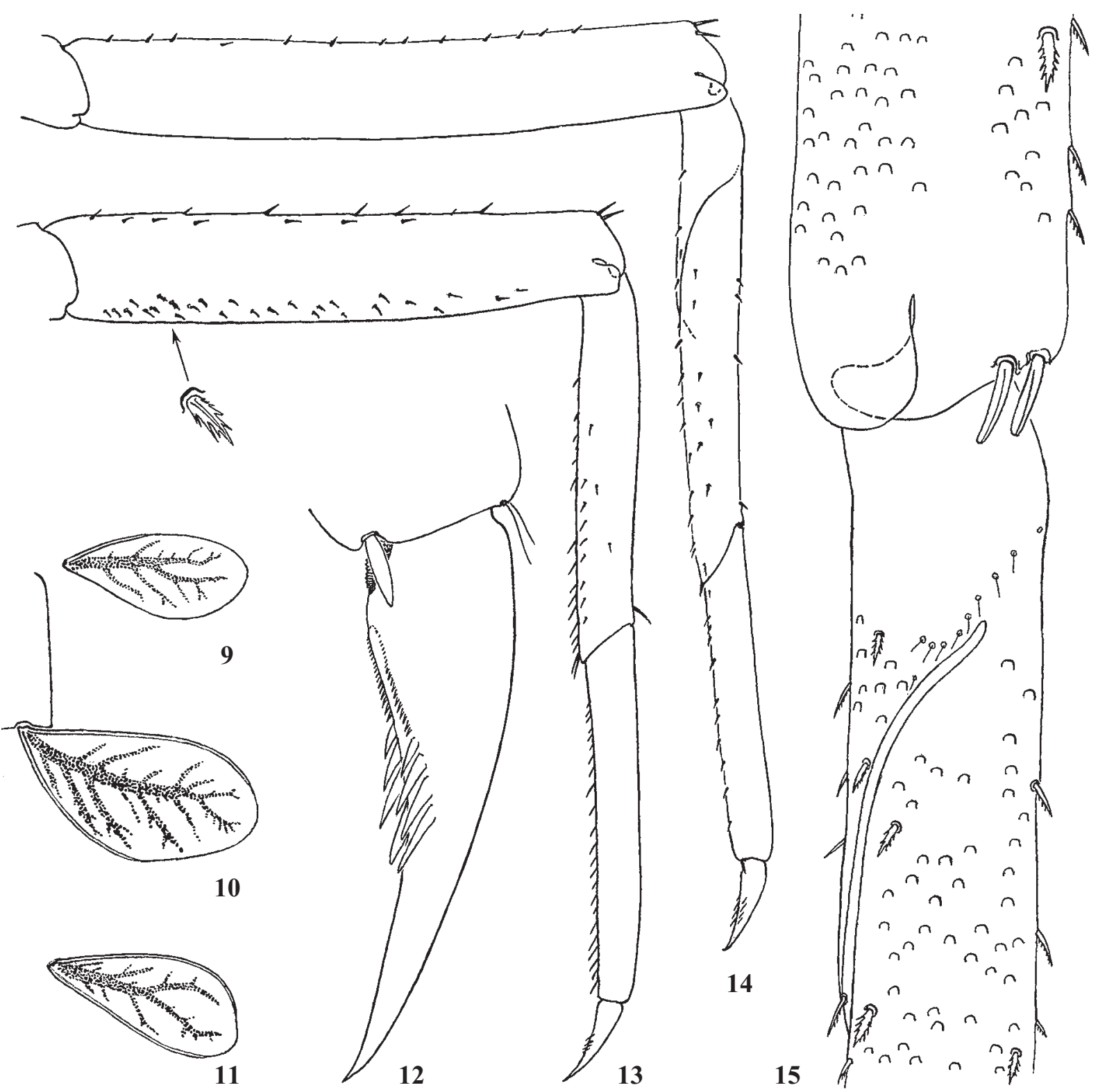

Figs 9-15. Indocloeon indonesiae sp.n., last instar larva: 9-11 — tergalii I, IV and VII; 12 - claw (holotype); 13 — fore leg, front view and enlarged bipectinate seta on ventral side of femur; 14 - hind leg, front view; 15 - femoro-tibial articulation of hind femur.

Рис. 9-15. Indocloeon indonesiae sp.n., личинка последнего возраста: 9-11 - тергалии I, IV и VII; 12 - коготок (голотип); 13 передняя нога, вид спереди, и увеличенная двоякогребенчатая щетинка на вентральной стороне бедра; 14 - задняя нога, вид спереди; $15-$ сочленение бедра и голени задней ноги. 
DISTRIBUTION. Known from a single point in Island Lombok (Indonesia).

COMPARISON. Larva of new species differs from $I$. primum by absence of dark brown boundary between frons and clypeus, more intensive cuticular coloration of head, thorax and legs, presence of setae on left mandible, absence of point on labial palp, non-fused denticles on abdominal terga and sterna, and enlarged spines on lateral sides of cerci.

Subimago and imago differ from I. primum by shape of postsubalar sclerite and by coloration: peculiar coloration of antennae, darker mesonotum and absence of reddish transverse stripes on abdominal terga. Subimago also differs from I. primum by pigmentation of postsubalar sclerite and lateral sclerite of postscutellum. Female imago also differs from $I$. primum by non-darkened crossveins and brown pigmentation of abdomen. Male imago also differs from I. primum by reddish tergum IX, brown gonostyli and penis and by absence of semicircular concavity on styliger.

\section{Indocloeon primum Müller-Liebenau, 1982} Figs 31-37.

MATERIAL. Sri Lanka, coll. N. Kluge and L. Sheyko: Uva province, Badulla district, Haputale, small stream in tea plantation, running from Haputale Forest, 15-23.I.2011: 19 L-S-IO', 12 L-S-Iㅇ, $3 \mathrm{~L}-\mathrm{S} \mathrm{O}^{\mathrm{T}}, 3 \mathrm{~L}-\mathrm{S} \bigcirc$, 128 larvae; Central province, Nuwara Elya district, Dalhausie (nr. Maskelya), very small stream close to hotel "Green

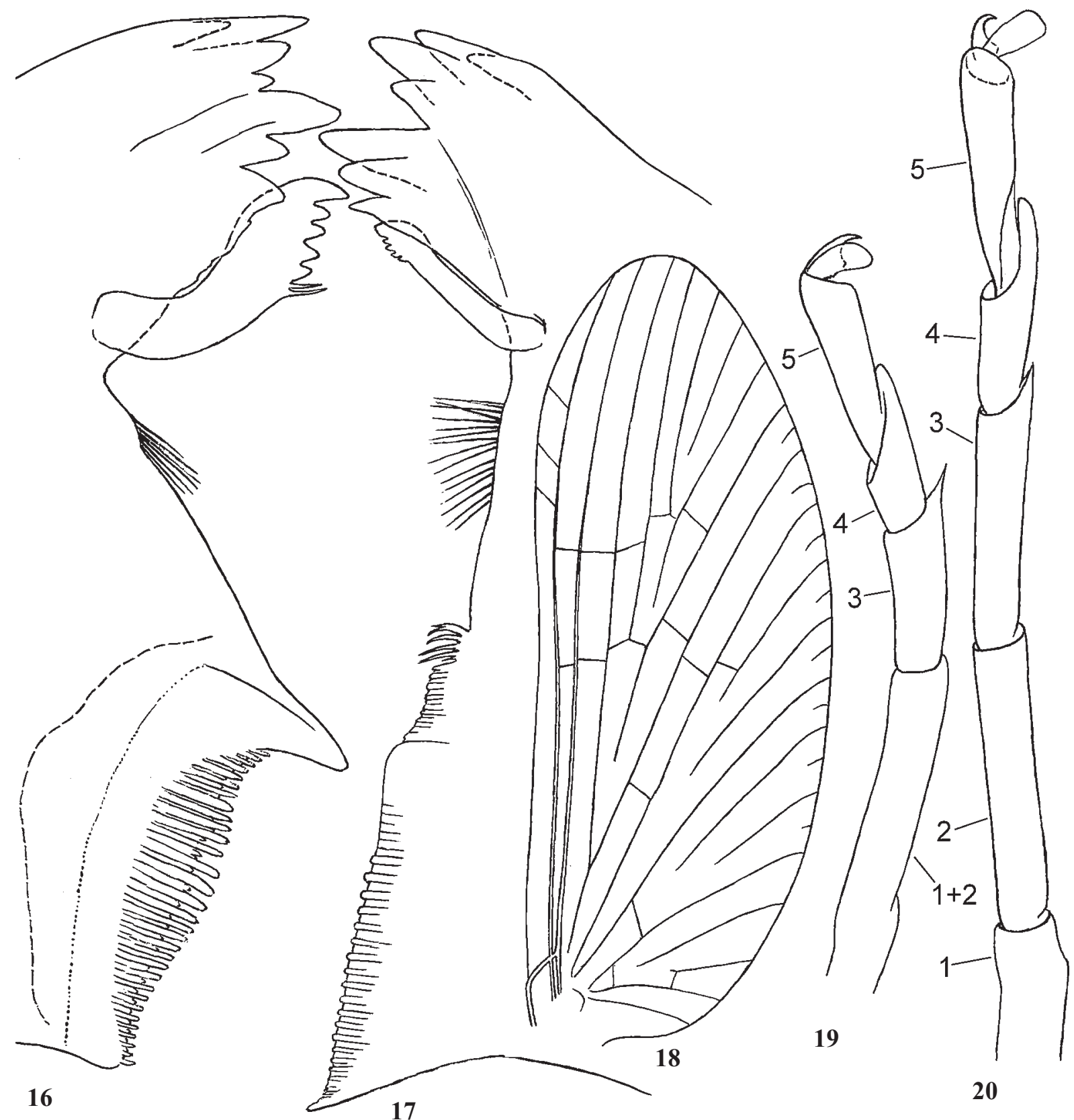

Figs 16-20. Indocloeon indonesiae sp.n.: 16-17 — cutting edges of left and right mandibles; 18 - fore wing (holotype); 19-20 - hind and fore tarsus of female imago; $1,2,3,4,5-1^{\text {st }}, 2^{\text {nd }}, 3^{\text {rd }}, 4^{\text {th }}$ and $5^{\text {th }}$ tarsomeres; $1+2-$ completely fused $1^{\text {st }}$ and $2^{\text {nd }}$ tarsomeres.

Рис. 16-20. Indocloeon indonesiae sp.n.: 16-17 — режущий край левой и правой мандибул; 18 - переднее крыло (голотип); 19-20 задняя и передняя лапки самки имаго; 1, 2, 3, 4, 5-1-й, 2-й, 3-й, 4-й и 5-й тарсомеры; 1+2 - полностью слитые 1-й and 2-й тарсомеры. 

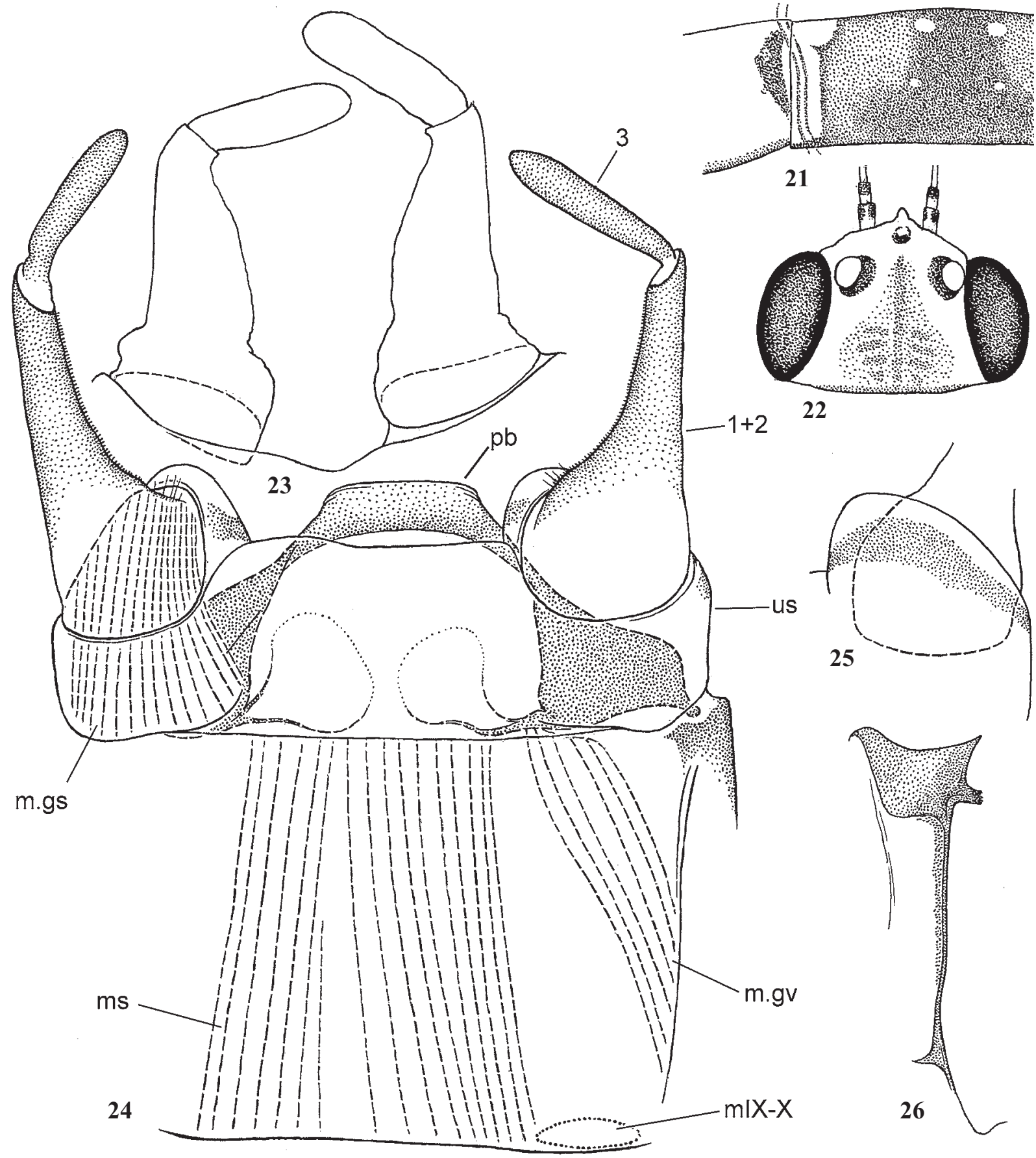

22

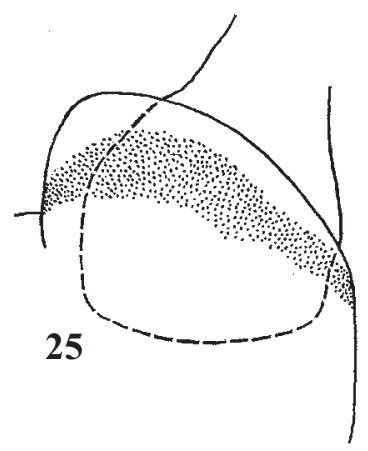

Figs 21-26. Indocloeon indonesiae sp.n. 21 — parts of abdominal tergum and sternum VIII of female imago, spread on slide; 22 — head of female imago; 23-25 - genitals of male, holotype; 23 - subimaginal exuviae of genitals; 24 — imaginal genitals, ventral view (hidden parts and muscles shown by interrupted lines; right gonostylar muscle and left retractor of gonovectis not shown); 25 - dorsal view of imaginal unistyliger; 26 - subimaginal exuviae of left postsubalar sclerite and lateropostnotal crest; $1+2-$ fused $1^{\text {st }}$ and $2^{\text {nd }}$ segments of gonostylus; $3-3^{\text {rd }}$ segment of gonostylus; m.IX-X - area of anterior attachment of right intersegmental ventral muscles going from base of $9^{\text {th }}$ segment to base of $10^{\text {th }}$ abdominal segment; m.gs - gonostylar muscle, located in unistyliger; m.gv — muscle-retractor of gonovectis; m.s - median sterno-styligeral muscle; $\mathrm{pb}$ - penial bridge; us - unistyliger.

Рис. 21-26. Indocloeon indonesiae sp.n. 21 - части VIII тергита и стернита брюшка самки имаго, расправлены на препарате; 22 - голова самки имаго; 23-25 - гениталии самца, голотип; 23 - субимагинальный экзувий гениталий; $24-$ имагинальные гениталии, вентрально (скрытые части и мышцы показаны прерывистыми линиями; правая гоностилярная мышца и левый ретрактор гоновектиса не показаны); 25 - имагинальный унистилигер, дорсально; 26 - субимагинальный экзувий постсубалярного склерита и латеропостнотального гребня; $1+2$ - слитые 1 -й и 2 -й членики гоностиля; 3 - $3-$ й членик гоностиля; m.IX-X- область переднего прикрепления правой межсегментарной мышцы, идущей от основания 9-го к 10-му сегменту брюшка; m.gs гоностилярная мышца, находящаяся в унистилигере; m.gv - мышца-ретрактор гоновекитиса; m.s - медиальная стерностилигеральная мышца; pb — мост пениса; us — унистилигер. 
House" near beginning of way to Sri Pada (Adam's Peak), 24 26.I.2011: 3 L-S-Iㅇ, 1 S-IO', 1 S-Iㅇ, 1 ㅇ imago, 6 larvae; Central province, Matale district, Sigiriya, 28-30.I.2011: 1 S-IO'.

LARVA. Cuticular COLORATIOn: Cuticle of head at most light brownish, with contrasting dark brown boundary between frons and clypeus. Pronotum and mesonotum light brownish, with diffusive lighter and darker markings; mesonotum with diffusive darker wide longitudinal median stripe; protoptera with darker and lighter stripes along some longi- tudinal veins. Thoracic pleura and sterna colorless. Legs colorless. All abdominal terga I-X nearly uniformly brown. Abdominal sterna lighter than terga [Müller-Liebenau, 1982: Fig. 2]. Caudalii nearly uniformly brown.

Hypodermal COlORATIOn: Each abdominal tergum can have more or less expressed reddish transverse band on posterior margin, as in imago.

SHAPE AND SETATION: Labrum usually with a paired row of several setae stretching from submedian seta to anterolateral

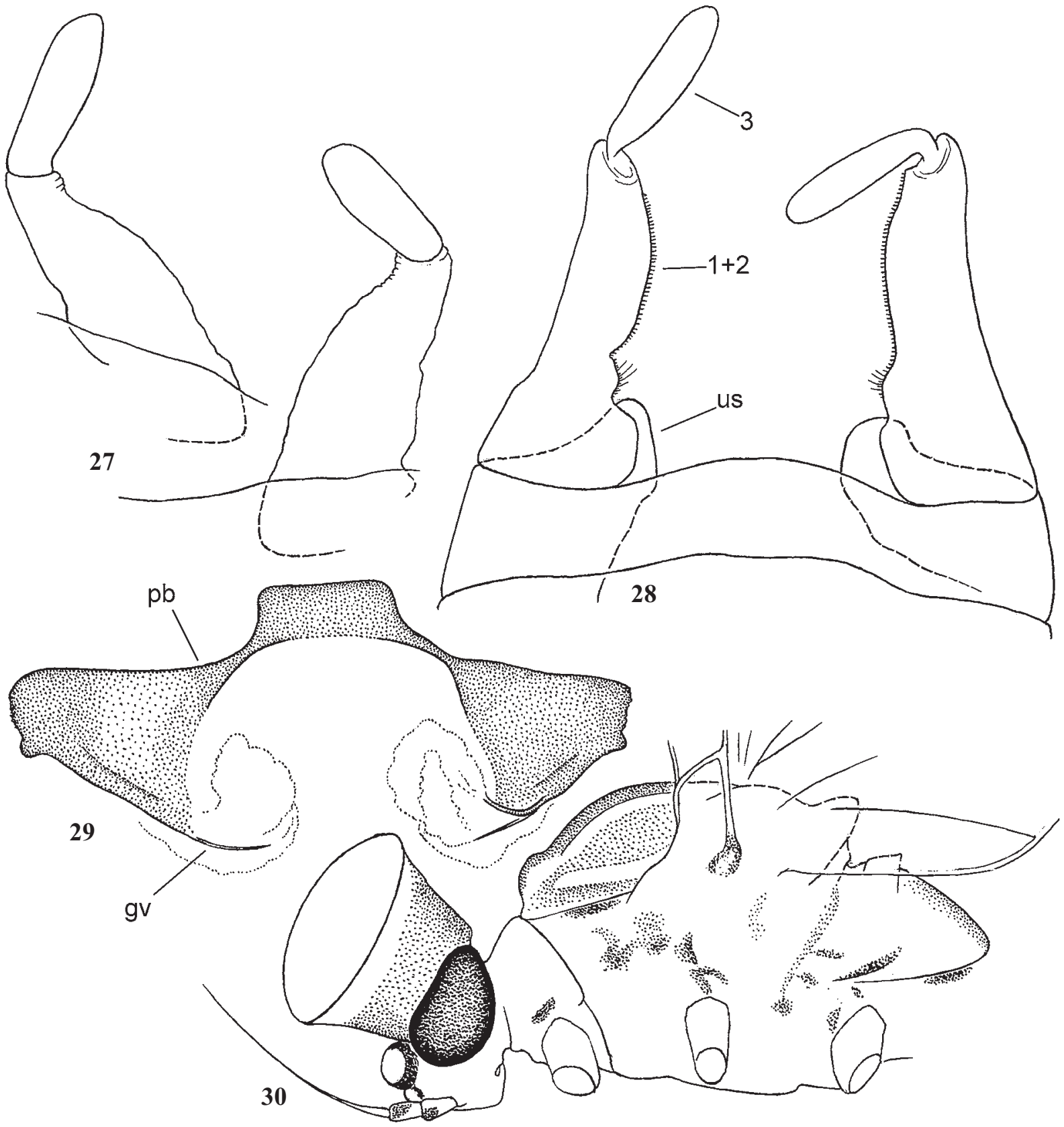

Figs 27-30. Indocloeon indonesiae sp.n.: 27-29 - genitals of male, paratype; 27 - subimaginal exuviae of left and right gonostyli; 28 - imaginal styliger and gonostyli, ventral view (dorsal outlines of unistyligers shown by interrupted lines); 29 — imaginal penis, ventral view; 30 - head and thorax of male imago (holotype); $1+2$ - fused $1^{\text {st }}$ and $2^{\text {nd }}$ segments of gonostylus; $3-3^{\text {rd }}$ segment of gonostylus; gv — gonovectis; $\mathrm{pb}$ - penial bridge; us - unistyliger.

Рис. 27-30. Indocloeon indonesiae sp.n.: 27-29 - гениталии самца, паратип; 27 - субимагинальные экзувии левого и правого гоностилей; 28 -имагинальный стилигер и гоностили, вентрально (дорсальные очертания унистилигеров показаны прерывистыми линиями); 29 - имагинальный пенис, вентрально; 30 - голова и грудь самца имаго (голотип); $1+2$ - слитые 1-й и 2-й членики гоностиля; 3 - 3-й членик гоностиля; gv — гоновектис; $\mathrm{pb}$ - мост пениса; us - унистилигер. 
margin [Müller-Liebenau, 1982: Fig. 1a]. Maxillary palp indistinctly 3-segmented, with remnant of $3^{\text {rd }}$ segment very short and bent inward [Müller-Liebenau, 1982: Fig. 1e]. Glossa narroved apically [Müller-Liebenau, 1982: Fig. 1d]. Projected medio-apical angle of $2^{\text {nd }}$ segment of labial palp sharply point- ed [Müller-Liebenau, 1982: Fig. 1b, c]. Hind margin of tergum I lacks denticles; hind margin of each tergum II-IX bears regular row of denticles fused together [Müller-Liebenau, 1982: Fig. 3]. Hind margins of sterna I-II lack denticles; each sternum III-VIII of male and each sternum V-IX of female

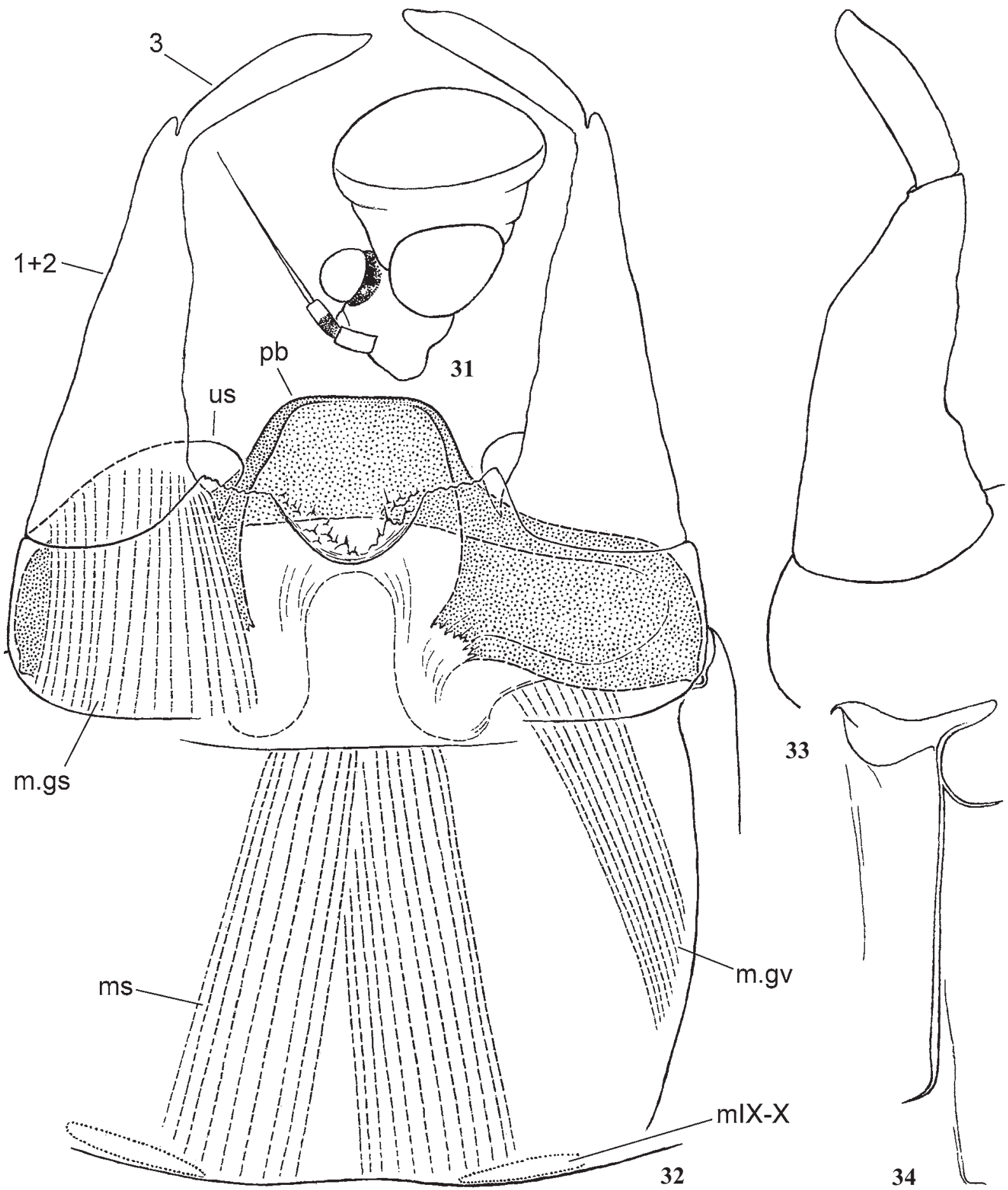

Figs 31-34. Indocloeon primum: 31 - head of male imago, lateral view; 32 - genitals of male imago, ventral view (hidden parts and muscles shown by interrupted lines; right gonostylar muscle and left retractor of gonovectis not shown); 33 — subimaginal exuviae of right gonostylus, the same individual; 34 - subimaginal exuviae of left postsubalar sclerite and lateropostnotal crest; $1+2-$ fused $1^{\text {st }}$ and $2^{\text {nd }}$ segments of gonostylus; $3-3^{\text {rd }}$ segment of gonostylus; m.IX-X — area of anterior attachment of right intersegmental ventral muscles going from base of $9^{\text {th }}$ segment to base of $10^{\text {th }}$ abdominal segment; m.gs - gonostylar muscle, located in unistyliger; m.gv — muscle-retractor of gonovectis; m.s - median sterno-styligeral muscle; pb - penial bridge; us — unistyliger. 


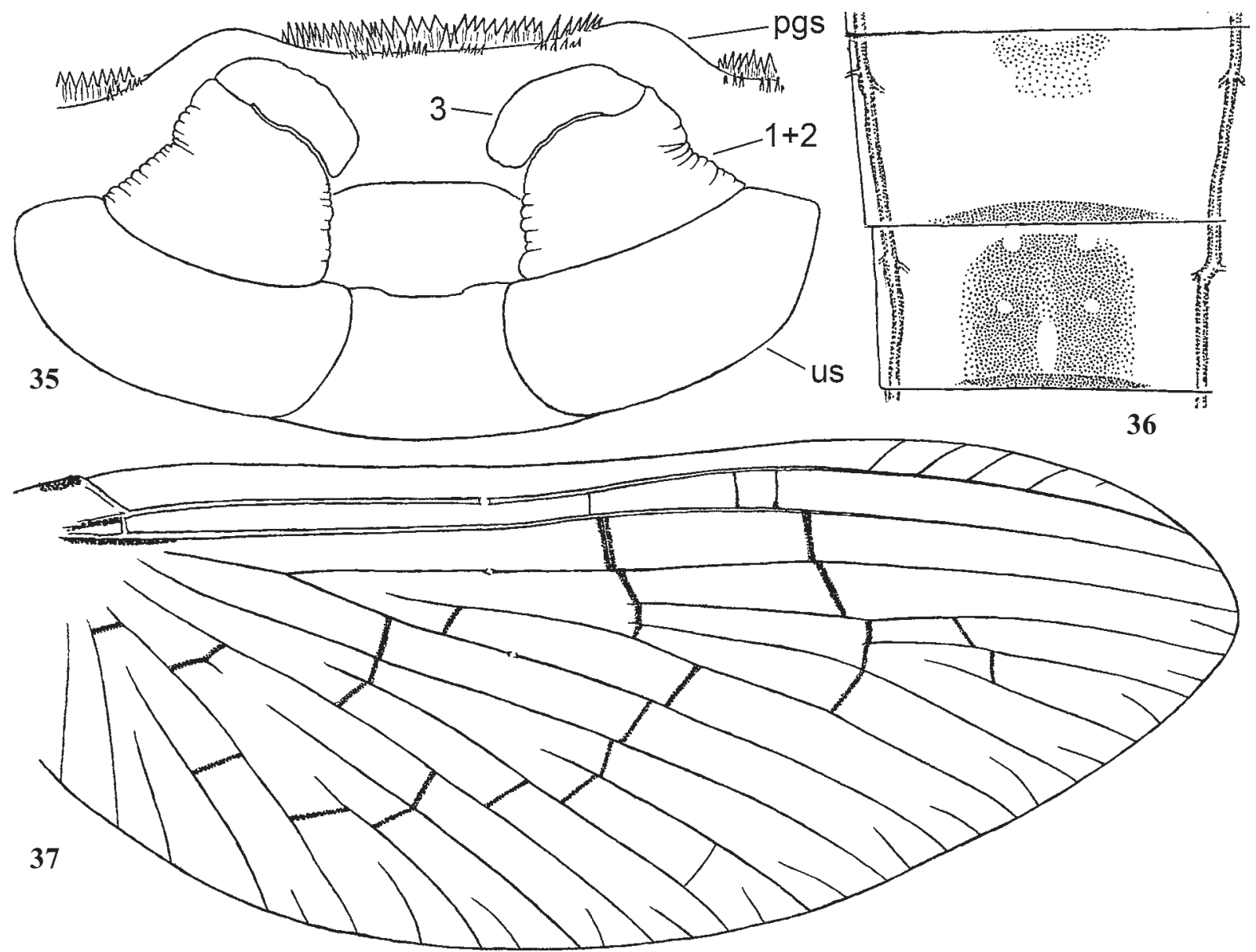

Figs 35-37. Indocloeon primum: 35 - subimaginal genitals folded under larval cuticle in mature male larva ready to molt to subimago (left gonostylar muscle shown by interrupted lines); 36 - abdominal terga VII and VIII of female imago, spread on slide; 37 - wing of female imago; $1+2-$ fused $1^{\text {st }}$ and $2^{\text {nd }}$ segments of subimaginal gonostylus; $3-3^{\text {rd }}$ segment of subimaginal gonostylus; pgs - larval protogonostylus; us - subimaginal unistyliger.

Рис. 35-37. Indocloeon primum: 35 - субимагинальные гениталии, сложенные под личиночной кутикулой у зрелой личинки самца, готовой линять на субимаго (левая гоностилярная мышца показана прерывистыми линиями); 36 - VII и VIII тергиты брюшка самки имаго, расправлены на препарате; 37 - крыло самки имаго; 1+2 - слитые 1-й и 2-й членики субимагинального гоностиля; 3 - 3-й членик субимагинального гоностиля; pgs — личиночный протогоностиль; us - субимагинальный унистилигер.

with fused denticles similar to denticles on terga. Sternum IX of male bears long thin pointed denticles by sides of protogonostyli and between protogonostyli. Unlike I. indonesiae, cerci have no long spines on each $4^{\text {th }}$ segment.

SUBIMAGO. CUTICULAR COLORATION: Cuticle nearly completely colorless, only margin of scutellum and knees tinged with brownish. Postsubalar sclerite colorless, with anterodorsal angle stretched and curved and postero-dorsal angle stretched to a long projection (Fig. 34). Wings light.

HYPODERMAL COLORATION: As in imago.

IMAGO, MALE. Head pale (ocher or white), sometimes with small brown $\operatorname{dot}(\mathrm{s})$. Antennae pale; scapus entirely pale, pedicellus with basal half brown (Fig. 31). Lateral eyes pale grayish. Turban eyes large, rounded (Fig. 31). Stems of turban eyes pale grayish; facetted surfaces vary individually from colorless whitish or yellowish to dull red or brownish. Thorax entirely pale (ocher or white), with a few small brown markings; sometimes medioscutum and scutellum slightly tinged with pale brownish. Legs colorless. Wings colorless; all veins pail, only junction of Sc, RA and costal brace tinged with brown; pterostigma with 2-5 crossveins; single marginal intercalary in each space (as in Fig. 37). Unlike female, crossveins thin and light; one non-reared specimen from Dalhausie has crossveins bordered by brown as in female. Abdominal segments I-VII translucent and colorless, with dark lateral tracheal trunks; each tergum II-VII with contrasting red or brown narrow transverse stripe on posterior margin, laterally these stripes are pointed and do not reach tracheal trunks (as in Fig.

Рис. 31-34. Indocloeon primum: 31 - голова самца имаго, латерально; 32 - гениталии самца имаго, вентрально (скрытые части и мышцы показаны прерывистыми линиями; правая гоностилярная мышца и левый ретрактор гоновектиса не показаны); 33 субимагинальный экзувий правого гоностиля, тот же экземпляр; 34 - субимагинальный экзувий постсубалярного склерита и латеропостнотального гребня; $1+2$ - слитые 1 -й и 2-й членики гоностиля; 3 - 3-й членик гоностиля; m.IX-X - область переднего прикрепления правой межсегментарной мышцы, идущей от основания 9-го к 10-му сегменту брюшка; m.gs - гоностилярная мышца, находящаяся в унистилигере; m.gv — мышца-ретрактор гоновектиса; m.s — медиальная стерно-стилигеральная мышца; рb — мост пениса; us - унистилигер. 
36); tergum VIII reddish medially, with white lateral parts; segments IX and X light. Cerci colorless.

Genitals as characterized for Indocloeon (Fig. 32), entirely colorless. Styliger medially with large concavity, which in ventral view looks as semicircular incision. Proximal $\left(1^{\text {st }}+2^{\text {nd }}\right)$ segment of gonostylus entirely covered with spine-like microtrichiae, which are longer on its inner side. Distal $\left(3^{\text {rd }}\right)$ segment of gonostylus with outer side convex and inner side straight or slightly concave, entirely covered with colorless blunt microlepides, which are longer on its inner side.

IMAGO, FEMALE. Head and thorax pale (ocher or white); head with yellow markings between eyes; antennae as in male; Pronotum with contrasting paired brown or reddish maculae. Legs colorless or diffusively tinged with reddish or yellowish. Behind anterior radial vein crossveins bordered by brown (Fig. 37) (in contrast to male). Coloration of abdomen similar to that of male: segments I-VII colorless, with dark lateral tracheal trunks; each tergum I-VII with contrasting red or brown narrow transverse stripe on posterior margin, laterally these stripes are pointed and do not reach tracheal trunks; tergum VIII reddish medially, with colorless lateral parts (Fig. 36); segment IX usually entirely colorless; tergum $\mathrm{X}$ reddish. One non-reared specimen from Dalhausie has, in addition to transverse stripes, a longitudinal median stripe on abdominal terga III-VI.

EGG. Oval, about $0.15 \mathrm{~mm}$ length; surface without macrorelief, with dense even punctuation, about $3-4$ elements per $0.01 \mathrm{~mm}$.

DIMENSION. Fore wing length 5-6 mm.

\section{Anafroptilum Kluge, gen.n.} Figs 38-55.

TYPE SPECIES: Centroptilum kazlauskasi Kluge, 1983.

ETYMOLOGY. Neutral gender. Can be interpreted either "non-Afroptlilum", or "non-African Centroptilum".

LARVA. Cuticle of abdominal terga with contrasting markings and blanks, which are species-specific and vary individually; tergum VI usually has most intensive dark markings [Lowen \& Flannagan, 1991: Fig. 13]; cuticle of abdominal sterna nearly colorless.

Head not wide; frons between antennae forms parallelsided elevation, whose margins can somewhat overlap antennal bases (Fig. 55). Both mandibles have incisor and kinetodontium separated nearly up to base; prostheca of left mandible has moderate width, terminates by several slender denticles; prostheca of right mandible very slender, terminates either by single point (kazlauskasi [Centroptilum]), or by two slender denticles (bifurcatum [Centroptilum]); setae proximad of prostheca present [Kluge, 1983: Figs115-116; Lowen \& Flannagan, 1991: Figs 17-18]. Median setae-like spines of hypopharynx very short. Maxilla has biting edge rather wide; 3 canines and distal dentiseta teeth-like, curved at the same direction; middle and proximal dentisetae more slender; maxillary palp long and slender, consists of 3 segments of subequal length [Kluge, 1983: Fig. 117; Lowen \& Flannagan, 1991: Fig. 19; Kluge \& Novikova, 1992: Fig. $3]$. Labium has paraglossal muscle fan-formed; $2^{\text {nd }}$ segment of labial palp narrower than $3^{\text {rd }}$ segment and contains muscle moving $3^{\text {rd }}$ segment; $3^{\text {rd }}$ segment strongly widened apically and truncate (Fig. 46) [Kluge, 1983: Fig. 118; Lowen \& Flannagan, 1991: Fig. 20; Kluge \& Novikova, 1992: Fig. 6]. Pronotum short, without projected antero-lateral angles [Kluge, 1983: Fig. 120], with straight transverse ridge near anterior margin; mesonotum with hind margin projected between protoptera. Metanotum with hind protoptera. Legs (Figs 38-40): Slender; femora of all legs slender and paral- lel-sided, fore femur somewhat thicker and shorter than middle and hind femora; fore tibia somewhat shorter than middle and hind tibiae; fore tarsus somewhat longer than middle and hind tarsi. Patella-tibial suture present on middle and hind legs (Fig. 39), absent on fore legs (Fig. 38). Femora, tibiae and tarsi have small stout pointed setae, which do not form regular rows; outer margin and apex of femur lack stout setae. Claw slender, slightly bent, with 2 rows of small denticles (Fig. 40).

Abdomen narrow, equally convex dorsally and ventrally: being spread on slide, terga and sterna have equal width. Lateral margins of abdominal segment IX and more anterior ones have pointed denticles (Fig. 41). Terga and sterna covered by fine scales situated in wide semicircular nests lacking operculae (Fig. 44). Tergalii able for rhythmical respiratory vibration. Tergalii I-VI with anal margin more convex than costal margin; tergalius VII with anal margin less convex than costal margin; costal rib far not reaching tergalius apex, anal rib less developed (Figs 47-53) [Lowen \& Flannagan, 1991: Fig. 21]. Cerci and paracercus have subequal length, not long, bear swimming setae nearly up to apex, in middle part have dark rings at apex of each $4^{\text {th }}$ segment [Lowen \& Flannagan, 1991: Fig. 13]; hind margin of each segment with denticles, no one of each reaches $1 / 2$ of segment length (unlike Procloeon/g1).

In mature male larva subimaginal gonostyli developing under larval cuticle are folded by "Cloeon-type": $2^{\text {nd }}$ segment bent laterally, $3^{\text {rd }}$ segment bent medially (Fig. 54).

SUBIMAGO AND IMAGO. Fore wings with no more than one marginal intercalary in each space. Hind wing more or less narrow, with curved costal projection [Kluge, 1983: Fig. 126; Lowen \& Flannagan, 1991: Fig. 5]. On middle and hind legs tibia slightly longer than femur; tarsus $1 / 2$ of tibia length; proximal $\left(1^{\text {st }}+2^{\text {nd }}\right)$ tarsal segment long; tarsus either has one apical thorn on $3^{\text {rd }}$ tarsomere only, while $1^{\text {st }}+2^{\text {nd }}$ and $4^{\text {th }}$ tarsomeres lack apical-ventral thorns (kazlauskasi [Centroptilum]), or has two apical thorns - on $1^{\text {st }}+2^{\text {nd }}$ and on $3^{\text {rd }}$ tarsomeres (bifurcatum [Centroptilum]); the same on fore leg of female. In subimago all segments of all tarsi covered with pointed microlepides. Male genitals similar to that of Cloeon/fg1 (Fig. 45): styligeral muscle well-developed; $2^{\text {nd }}$ segment of gonostylus (fused with $1^{\text {st }}$ segment) narrower than $1^{\text {st }}$ segment, widened apically; distal $\left(3^{\text {rd }}\right)$ segment petiolate; penial bridge with wide median projection; gonovectes completely fused with penial bridge.

COMPARISON. Formerly representatives of Anafroptilum were attributed to Centroptilum. In contrast to Centroptilum and other Anteropatellata, Anafroptilum has primitive position of patello-tibial suture, characteristic for Protopatellata: In larva, subimago and imago of both sexes patella-tibial suture is developed only on middle and hind legs, being absent on fore legs (Figs 38, 39).

The following characters of Anafroptilum are in common with Centroptilum and Cloeon/fg1 (incl. Procloeon): Labial palp has $3^{\text {rd }}$ segment truncate and $2^{\text {nd }}$ segment non-projected. Larval legs slender; femur parallel-sided, without row of setae on outer margin and without two apical setae; claw slender, with two rows of denticles. Larval abdominal terga with scales situated in semicircular nests lacking operculae at angles. Larval caudalii in middle part with dark rings at apex of each $4^{\text {th }}$ segment.

The following characters of Anafroptilum are in common with Cloeon/fg1 (incl. Procloeon): Segments VIII and IX with spines forming longitudinal rows on lateral margins. Gonovectes fused with penial bridge (in contrast to Centroptilum). 
DISTRIBUTION. East Palaearctic and Nearctic.

SPECIES COMPOSITION. Includes a single East-Palaearctic species Anafroptilum kazlauskasi (Kluge, 1983) comb.n. and several Nearctic species, among which only Anafroptilum bifurcatum (McDunnough, 1924) comb.n. is examined by me.

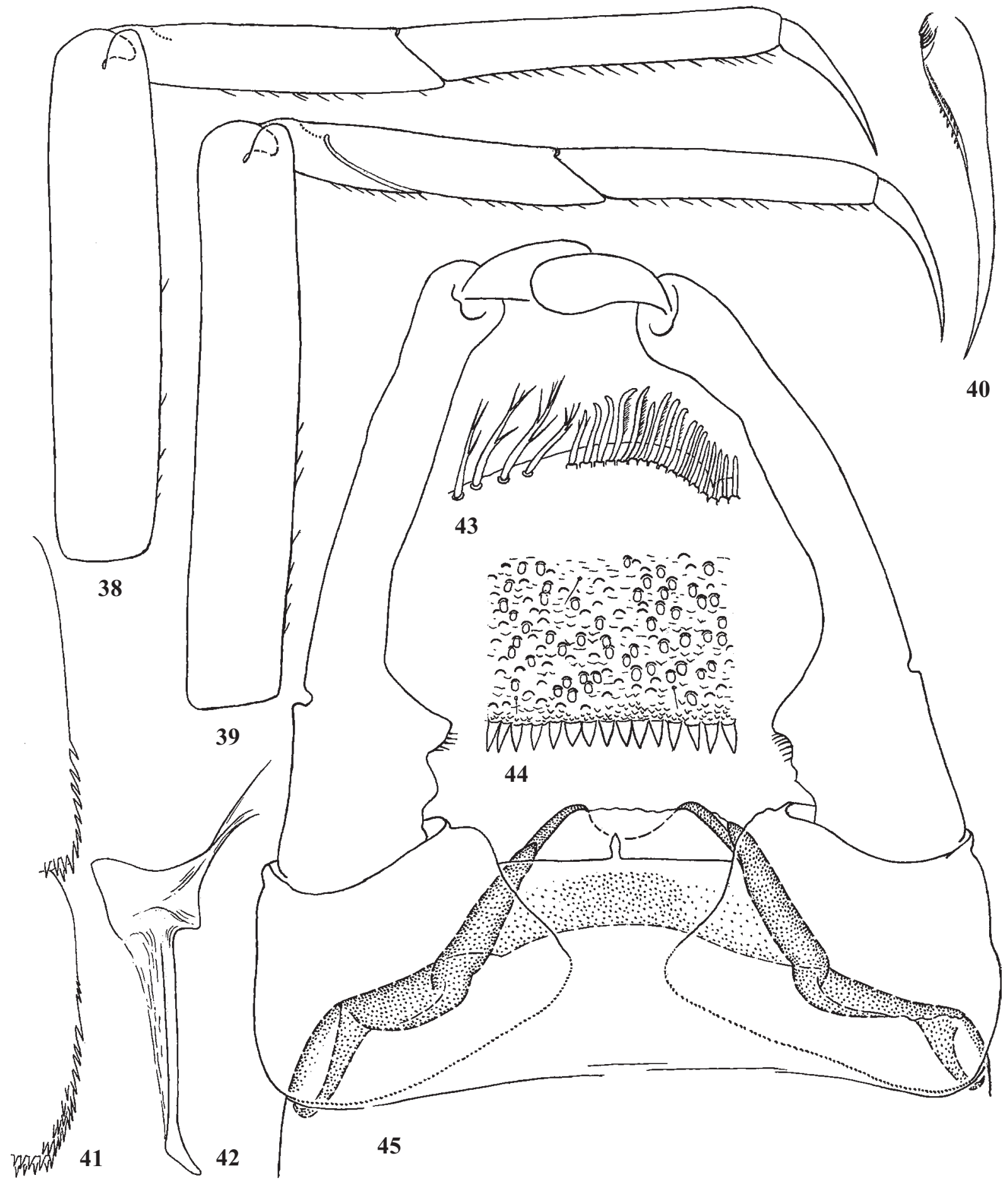

Figs 38-45. Anafroptilum kazlauskasi: 38 - larval fore leg, front view; 39 - larval hind leg, front view; 40 - claw; 41 - lateral margins of larval abdominal segments VIII and IX; 42 - subimaginal exuviae of left postsubalar sclerite and lateropostnotal crest; 43 - setae on fore margin of labrum; 44 - hind margin of larval abdominal tergum; 45 - genitals of male imago, ventral view (hidden parts of penis shown by interrupted lines).

Рис. 38-45. Anafroptilum kazlauskasi: 38 - передняя нога личинки, вид спереди; 39 - задняя нога личинки, вид спереди; 40 коготок; 41 - латеральные края VIII и IX сегментов брюшка личинки; 42 — субимагинальный экзувий постсубалярного склерита и латеропостнотального гребня; 43 - щетинки на переднем крае верхней губы; 44 — задний край тергита брюшка личинки; 45 — гениталии самца имаго, вентрально (скрытые части пениса показаны прерывистыми линиями). 


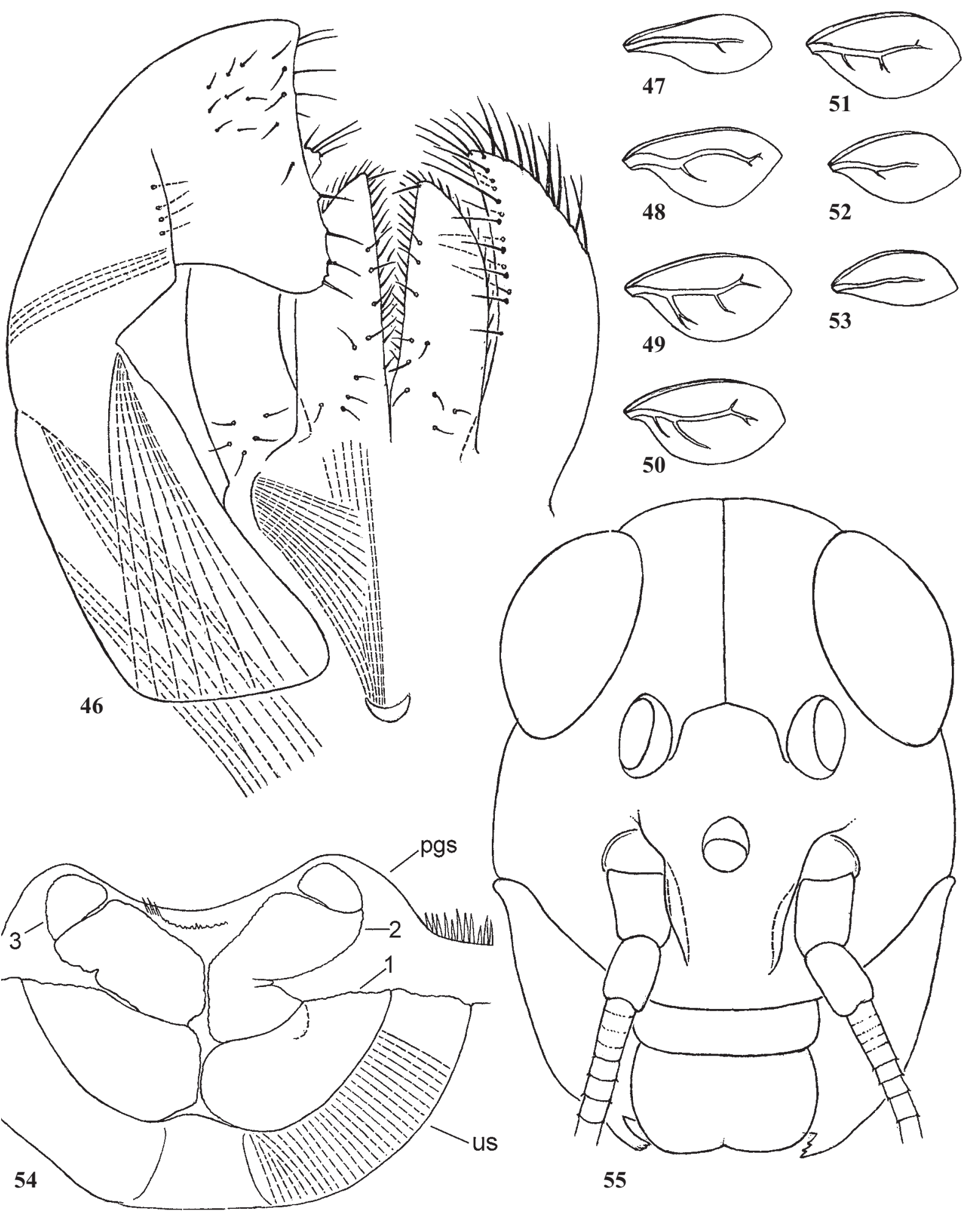

Figs 46-55. Anafroptilum kazlauskasi: 46 - half of labium, ventral view (muscles and setae on dorsal side of $2^{\text {nd }}$ palpomere shown by interrupted lines); 47-53 - tergalii I-VII; 54 - subimaginal genitals folded under larval cuticle in mature male larva ready to molt to subimago (right gonostylar muscle shown by interruptede lines); 55 - head of female larva, front view; $1,2,3-1^{\text {st }} 2^{\text {nd }}$ and $3^{\text {rd }}$ segments of subimaginal gonostylus; pgs - larval protogonostylus; us - subimaginal unistyliger.

Рис. 46-55. Anafroptilum kazlauskasi: 46 - половина нижней губы, вентрально (мышцы и щетинки на дорсальной стороне второго членика щупика показаны прерывистыми линиями); 47-53 - тергалии I-VII пар; 54 - субимагинальные гениталии, сложенные под личиночной кутикулой у зрелой личинки самца, готовой линять на субимаго (правая гоностилярная мышца показана прерывистыми линиями); 55 - голова личинки самки, вид спереди; 1, 2, 3 - 1-й, 2-й и 3-й членики субимагинального гоностиля; pgs - личиночный протогоностиль; us - субимагинальный унистилигер. 
Anafroptilum kazlauslasi (Kluge, 1983) comb.n. Figs 38-55.

Centroptilum kazlauskasi Kluge, 1983.

Cloeon (Centriptilum) kazlauskasi: Kluge \& Novikova, 1992. MATERIAL. RUSSIA, Promorskiy Territory: river Sidime (= Narva) near natural reserve «Kedrovaya Pad'», 13-21.VII.1980, coll. N. Kluge: 2 L-S-I $\sigma^{7}$ (holotype and paratype), 3 L-S-I 9 (paratypes), $3 \mathrm{~L}-\mathrm{S}+$ (paratypes), 2 larvae (paratypes); river Serebryanka near Terney, 15-19.VIII.1990, coll. N. Kluge: 2 L-S-IO', 3 LS ${ }^{\top}, 3$ L-S-I + , 8 larvae.

Imago and larva are described in my previous peper [Kluge, 1983]. Larva and female imago (as well, as male imago) have patella-tibial suture absent on fore leg and present on hind legs (Figs 38-39) (as in other Protopatellata, unlike Centroptilum). Penis has gonovectes completely fused with penial bridge (Fig. 45) (as in other Anafroptilum, unlike Centroptilum).

\section{Anafroptilum bifurcatum (McDunnough, 1924)} comb.n.

Centroptilum bifurcatum McDunnough, 1924

MATERIAL. USA, Nebraska, Cherry Co., R+61, Snake River, 6.VI.1995, coll. B. Kondratieff: $4 \mathrm{IO}^{\top}, 1 \mathrm{~S}^{\top}, 3 \mathrm{I}+$, 4 larvae, 2 larval exuviae.

Male imago is described by McDunnough [1924, 1929] and Lowen \& Flannagan [1991]; larva is described by Lowen \& Flannagan [1991]. Basing on the material examined, it should be added, that larva and female imago (as well, as male imago) have patella-tibial suture absent on fore leg and present on hind legs (as in other Protopatellata, unlike Centroptilum). Penis has gonovectes completely fused with penial bridge (as in other Anafroptilum, unlike Centroptilum).

\section{Systematic position of Anafroptilum and status of Centroptilum}

Till present, all species of Anafroptilum were attributed to the genus Centroptilum Eaton, 1869. Traditionally, the genus Centroptilum was acceped in wide sense and included all baetid species, which do not belong to Baetovectata and retain hind wings. Later the genus Centroptilum was restricted to exclude African species belonging to Protopatellata [Gillies, 1990] and to exclude Holarctic species related to Procloeon [McCafferty \& Waltz, 1990; Kluge \& Novikova, 1992].

Formerly we assumed that in such restricted sense the taxon Centroptilum should be represented in Palaearctic by 3 species: (1) luteolua Müller, 1776 [Ephemera] (the type species of Centroptilum), (2) kazlauskasi Kluge, 1983 [Centroptilum] and (3) undescribed species named "Cloeon (Centroptilum) sp.n.1" [Kluge \& Novikova, 1992]. But the last one, as appears from newly collected material, actually belongs not to $\mathrm{Cen}$ troptilum, but to Procloeon/g1 (see classification above). The species kazlauskasi [Centroptilum] is moved now to Anafroptilum. Thus, Centroptilum is represented in the Old World by a single species Centroptilum luteolum (Müller, 1776).

Centroptilum differs from Cloeon/fg1 (see classification above) and Anafroptilum by retention of free gonovectes, which are not fused with penial bridge [Grandi, 1960: Fig. XI.3]. In contrast to Cloeon/fg1 and Anafroptilum, larva of Centroptilum has no longitudi- nal rows of spines on lateral margins of last abdominal segments; instead of it, in Centroptilum luteolum the whole surface of all abdominal segments is evenly and densely covered by minute spines.

Systematic position of Anafroptilum is vague: On the one hand, it has apomorphies of Cloeon/fg1: longitudinal rows of spines on larval abdominal segments VIII and IX (sometimes also on previous segments) are present in Anafroptilum and Cloeon/fg1, being not found in other taxa; truncate labial palp and dark rings on each $4^{\text {th }}$ segment of caudalii are characteristic for Anafroptilum and Cloen/fg1, being found in some other taxa; fusion of gonovectes with penial bridge, besides Anafroptilum and Cloeon/fg1, is known for Rhithrocloeon/ g1 [g: Rhithrocloeon Gillies, 1985] (including Mutelocloeon Gillies \& Elouard 1990, Bugilliesia Lugo-Ortiz \& McCafferty, 1996 and Kivuiops Lugo-Ortiz \& McCafferty, 2007), which belongs to Protopatellata. On the other hand, all representatives of Cloeon/fg1 have patella-tibial suture equally developed on all legs of larva and female adult, that is an autapomorphy of Anteropatellata, while Anafroptilum has a primitive position of patella-tibial suture on middle and hind legs only, as in the plesiomorphon Protopatellata. Such characters as two rows of denticles on larval claws and single marginal intercalaries of fore wings, are symplesiomorphies of Protopatellata and Cloeon/fg1. Scales in semicircular nests are found in various non-related taxa, including all Cloeon/fg1, but they are not characteristic for Protopatellata, which often have scales in angulate nests with operculae (Fig. 6).

ACKNOWLEDGEMENT. Author thanks Boris Kondratieff (Colorado State University) for material on bifurcatum [Centroptilum]. This investigation was supported by the Russian Federal Program for Support Leading Scientific Schools, grant No. 332.2010.4.

\section{References}

Gillies M.T. 1990. A revision of the African species of Centroptilum Eaton (Baetidae, Ephemeroptera) // Aquatic Insects. Vol.12. No.2. P.97-128.

Grandi M. 1960. Contributi allo studio degli Efemeroidei italiani. XXIII. Gli organi genitali esterni maschili degli Efemeroidei // Bollettino dell'Istituto di Entomologia della Università di Bologna. Vol.24. P.67-120.

Kluge N.J. 1983. [New and little known mayflies of the family Baetidae (Ephemeroptera) from Primorye Territiry] // [Entomologicheskoe Obozrenie]. Vol.61. No.1. P.65-79. [in Russian, English translation: Entomoljgical Review. Vol.62. No.1. P.5368].

Kluge N.J. 1997. Classification and phylogeny of the Baetidae (Ephemeroptera) with description of the new species from the Upper Cretaceous resins of Taimyr // P. Landolt \& M. Sartori (eds.). Ephemeroptera \& Plecoptera. Biology-Ecology-Systematics (Proc. VIII Int. Conf. on Ephemeroptera and XII Int. Symposium on Plecoptera, August 1995, Losanne). Mauron+ Tinguely \& Lacht SA, Fribourg/Switzerland. P.527-535.

Kluge N.J. \& Novikova E.A. 1992. [Revision of the Palaearctic genera and subgenera of mayflies of the subfamily Cloeoninae (Ephemeroptera, Baetidae) with description of new species from the USSR] // [Entomologicheskoe Obozrenie]. Vol.71. No.1. 
P.60-83 [in Russian, English translation: Entomological Review. Vol.71. No.9. P.29-54.

Kluge N.J. \& Novikova E.A. 2011. Systematics of the mayfly taxon Acentrella (Ephemeroptera, Baetidae), with description of new Asian and African species // Russian Entomological Journal. Vol.20. No.1 P.1-56.

McCafferty W.P. \& Waltz R.D. 1990. Revisionary synopsis of the Baetidae (Ephemeroptera) of North and Middle America // Transactions of the American Entomological Society. Vol.116. No.4. P.769-799.

Lowen R.G. \& Flannagan J.F. 1991. Four Manitoba species of Centroptilum Eaton (Ephemeroptera: Baetidae) with remarks on the genus // Alba-Tercedor J. \& Sanchez-Ertega A. (eds).
Overview and strategies of Ephemeroptera and Plecoptera (Proc. 6th Int. Congf. Ephemeroptera \& 10th Int. Symp. Plecoptera, 24-30 July 1989, Granada, Spain). Sandhill Crane Press. P.189-205.

McDunnough J. 1924. New Canadian Ephemeridae with notes, II. // The Canadian Entomologist (1923). Vol.55. P.90-98, 113-122, $128-133$.

McDunnough J. 1929. Notes on North American Ephemeroptera with descriptions of new species. II. // The Canadian Entomologist. Vol.61. P.169-180.

Müller-Liebenau I. 1982. A new genus and species of Baetidae from Sri Lanka (Ceylon): Indocloeon primum gen.n., sp.n. (Insecta, Ephemeroptera) // Aquatic Insects. Vol.4. No.3. P.125-129. 